\title{
Tibuana
}

\section{p-ISSN 2622-2027 \\ $e$-ISSN 2622-2035 \\ VERTICAL AXIS WIND TURBINE DESIGN FOR MOVEMENT PERMANENT MAGNETIC GENERATORS OF AXIAL TYPE}

\author{
Budi Prijo Sembodo ${ }^{1}$, Titik Koedijati ${ }^{2}$, Abdul Jumali ${ }^{3}$ \\ Electrical Engineering Department ${ }^{1}$, Industrial Engineering Department ${ }^{2,3}$, \\ Faculty of Industrial Technology \\ University of PGRI Adi Buana Surabaya \\ Email : budi@unipasby.ac.id
}

\begin{abstract}
One of the alternative energy source that can be developed is the Wind Power Plant. The need for electrical energy that continues to increase, it takes not a little time to build a power plant. System planners must also be able to see the possibilities of the development of the power system in the years to come. Indonesia is a country that has abundant energy resources, one of which is a source of wind energy. Indonesia which is an archipelagic country and one of the countries located on the equator is a factor, that Indonesia has abundant wind energy potential. In this study the output that produced is a renewable energy product, which is a power plant product in the coastal area. In the previous study a low-speed permanent magnet generator has been produced which can be driven by wind turbines which will be continued through the design of vertical type wind turbines. The results of this study can then be developed, especially for electricity generation products in the coastal region. In the process of planning and manufacturing vertical type wind turbines, to produce enough power to meet household electricity needs should be based on several factors that support the effectiveness of the power produced by the turbine, namely: Turbine Dimensions (Length and Blade Width), Material Strength , Shaft, Bearing and Generator Shaft
\end{abstract}

\section{Keyword :}

\section{INTRODUCTION}

The construction of large-scale power plants is often constrained by the size of the investment and the long period of development in the centers of electricity compared to other industrial developments, so it is necessary to try to meet the electricity needs on time. which is reduced like the use of fossil fuels. Wind energy is relatively clean and environmentally friendly because it does not produce $\mathrm{CO} 2$ carbon dioxide or other harmful gases in global warming, sulfur dioxide and nitrogen oxides (the type of gas that causes acid rain).

Bambang Setioko (2007), in his research encouraged people to look for new alternatives that were cheap and easily obtained to get mechanical power into electricity. Wind power is a cheap and easily available motion force, so this is used as a research and is used to drive electric generators to produce electricity. Data processing and analysis techniques in the manufacture of wind turbines are made by taking data on the number of fans, the size of the angle, wind speed, and the number of turns

Indonesia is a country that has abundant energy resources, one of which is a source of wind energy. Indonesia which is an archipelagic country and one of the countries located on the equator is a factor, that Indonesia has abundant wind energy potential. Basically the wind occurs because there is a temperature difference between hot air and cold air. In the equator, the air becomes hot and expands and becomes lighter, rises upward and moves to cooler areas. Conversely the polar regions are cold, the air cools and drops down. Therefore air circulation occurs in the form of transfer of air from the north pole to the equator along the surface of the earth and vice versa an air displacement from the equator returns to the north pole, through 


\section{Tibuana}

Journal of applied Industrial Engineering-University of PGRI Adi Buana

$p$-ISSN 2622-2027

$e$-ISSN 2622-2035

a higher layer of air. The potential of wind energy in Indonesia is quite adequate, because the average wind speed ranges from 3.5 to $7 \mathrm{~m} / \mathrm{s}$. The mapping results of the National Aeronautics and

Space Agency (LAPAN) at 120 locations showed that several regions had wind speeds above $5 \mathrm{~m} / \mathrm{s}$, each of East Nusa Tenggara, West Nusa Tenggara, South Sulawesi, and the South Coast of Java.

Table 1 Clasification of wind energy potential, utilization and potential location.

\begin{tabular}{ccccc}
\hline Level & $\begin{array}{c}\text { Wind Speed } \\
(\mathbf{m} / \mathbf{s})\end{array}$ & $\begin{array}{c}\text { Specification of power } \\
\left(\mathbf{W} / \mathbf{m}^{\mathbf{2}}\right)\end{array}$ & $\begin{array}{c}\text { Capacity } \\
(\mathbf{k W})\end{array}$ & Destination \\
\hline Small & $2,5-4,0$ & $<75$ & s/d 10 & $\begin{array}{c}\text { Java, NTB, } \\
\text { NTT, Maluku, } \\
\text { NTB, NTT,Sulsel, } \\
\text { Sultra }\end{array}$ \\
Midle & $4,0-5,0$ & $75-150$ & $10-100$ & $\begin{array}{c}\text { NTh } \\
\text { Sulsel, NTB, NTT, } \\
\text { East Beach of java }\end{array}$ \\
High & $>5,0$ & $>150$ & $>100$ & \\
\hline
\end{tabular}

Reference: LAPAN, 2005

\section{DESIGN CALCULATION}

Sulistyo atmadi (2008), representing the National Institute of Aeronautics and Space (LAPAN) examined the development of savonius type vertical axis wind turbine rotor method. This research was developed with the method of determining the initial parameters of the savonius type vertical axis wind turbine rotor. With certain power and wind speed, the rotor's range, diameter, height and rotational speed can be known. The area of the rotor is strongly influenced by the power coefficient. The rotor rotation speed

$$
\mathrm{P}=\operatorname{Cpr} \frac{1}{2} \rho A v^{3}
$$

Rotor Power Coeficient, the power coefficient will be calculated using the strip theory for a certain rotor speed ratio. This gives the rotor power coefficient for different wind speeds at

$$
C p r=\lambda C q
$$

Tip speed ratio is the ratio of the speed of the rotor tip to free wind speed. For certain

nominal wind speeds, the tip speed ratio will affect the rotational speed of the rotor.

a fixed rotor speed or for different rotor speeds at one wind speed. can be calculated after the rotor diameter is calculated and the Speed Ratio Tip is determined

\subsection{Dimension of Turbine}

In designing a turbine, the turbine must have a type and dimension, to determine the type of turbine used is calculated based on the speed of angina in the surrounding conditions. The dimensions of a wind turbine can be searched by assuming that power is generated at the speed of the wind that occurs around us. With the power formula $(\mathrm{P})$ in the wind turbine as follows (Eric Hau:2005) :

The following graph shows the variation of the

$$
\lambda=\frac{\pi \nu \pi}{60 v^{v}}
$$
tip speed ratio and power coefficient $(\mathrm{Cp})$ values for various wind turbines.

\footnotetext{
values for various wind turbines.
}

TiBuana, Vol.2, No.2, $2019 \mid 59$ 


\subsection{Strength of turbine shaft}

This machine element is a very important part, besides the shaft functions as the position of the blade, the shaft also serves as the main means of connecting energy changes, from kinetic energy to electrical energy previously through the generator.

Based on this type of turbine, the shaft is mounted vertically so that it gets a greater torsional load.

Calculation of shaft diameter (Sularso:1983)

$$
\begin{gathered}
\mathrm{Pd}=\mathrm{f}_{\mathrm{C}} \mathrm{P} \\
\mathrm{T}=9,74 \times 10^{5} \frac{r_{\mathrm{d}}}{\mathrm{w}} \\
\iota_{\boldsymbol{u}}=\frac{a_{b}}{s_{f 1} \times s_{f 2}} \\
d_{s}=\left(\frac{v_{-},}{\tau_{a}} K_{t} C_{b} T\right)^{1 / 3}
\end{gathered}
$$

\subsection{Bearing Calculation}

Bearings are machine elements that support the load shaft, so that the rotation

$$
\begin{aligned}
& P=\frac{w}{l a} \\
& \frac{l}{a} \leq \sqrt{\frac{1}{5.1} \frac{\mathrm{au}}{p a}} \\
& V=\pi d \frac{n}{60 \mathrm{w} 1000}
\end{aligned}
$$

\subsection{Torsion calculation}

$$
T=\frac{n p x \text { ss.ovu }}{n}
$$

Determination of Pitch Line Diameter By assuming a $\mathrm{P}$ value, the

$$
T=F_{\mathrm{r}} \frac{a_{p}}{2}
$$

The amount of torque can be calculated by the equation (Khurmi: 2005):

So that from these prices if substituted

into the equation:

or alternating motion can take place smoothly, safely, and last long. (Sularso, 1983). Bearing planning calculation: 


\subsection{Calculation of Turbine Blade}

Which :

$\mathrm{P}=150$ watt

Power on the turbine $: \mathrm{P}=C \operatorname{pr} \frac{1}{2} \rho A v^{3}$

\section{a. Calculation of Tip Speed Ratio (TSR)}

$\mathrm{D}=1.25 \mathrm{~m}$

$\mathrm{n}=45 \mathrm{rpm}$ (assumption)

$$
\begin{aligned}
& \lambda=\frac{\pi D n}{60 v} \\
& \lambda=\frac{3,14 \times 1,25 \times 45}{60 \times 5,6}
\end{aligned}
$$

$\lambda=0,52$
$\mathrm{V}=5,6 \mathrm{~m} / \mathrm{s}$

$\mathrm{N}=45 \mathrm{rpm}$ (assumption) $\mathrm{v}=5,6 \mathrm{~m} / \mathrm{s}$ (based on measurement data)

Tip Speed Ratio $(\lambda)$

\section{b. Determ Rotor Torque Coeficient (Cqr)}

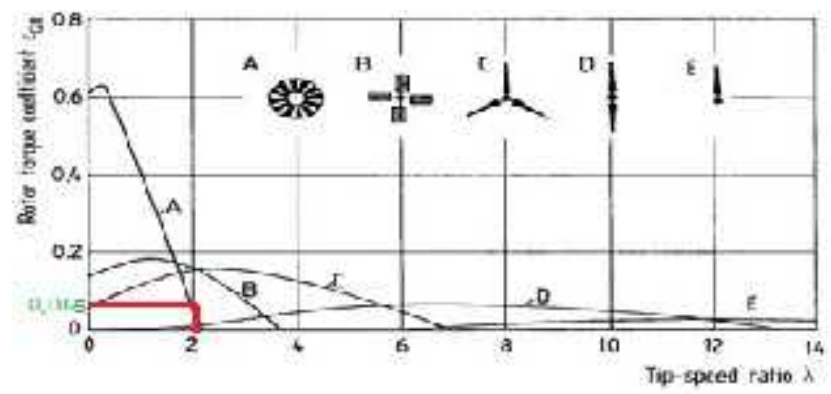

Picture 1. Coefficient of Rotor of Some Wind Turbines

Based on the picture of the relationship of the rotor coefficients of several wind turbines obtained for savonius turbine rotor in area $\mathrm{A}$ if $\lambda_{1}=2$ then $\mathrm{Cq}_{1}=$

Determining Rotor Power Coeficient (Cpr) Which :

$\lambda=0,52 \mathrm{Cq}=0,25 C p r=\lambda \times C q r \mathrm{Cpr}$ $=0,52 \times 0,25 \mathrm{Cpr}=0,13$

Area on the turbine blade :

$\mathrm{P}=$

$$
\operatorname{Cpr} \frac{1}{2} \rho V^{3} A
$$

By obtaining a cross-sectional area of 6 blades (A) of $11,4 \mathrm{~m}^{2}$, then
0,065. So if $\lambda_{2}=0,52$, then $\mathrm{Cq}_{2}=$ $\frac{\lambda_{1}}{\lambda_{2}} \times 0.065=$

$$
\begin{aligned}
& A=\frac{2 P}{C p r \mu v^{3}} \\
& A=\frac{2 \times 150}{0,13 \times 1,15 \times 5,6^{3}} \\
& A=11,4
\end{aligned}
$$

using 6 blades the blade dimensions are obtained as follows : 
1. Wide Tube Blanket

Which :

Blade height $(\mathrm{L})=2$ meters

Number of blades $=6$ pieces

Area of 1 blade $=\frac{11,4}{6}=1,9 \mathrm{~m}$

$$
A=\frac{1}{2} \pi d L
$$

2. Broad Arm Length (A2)

With an arm length of $70 \mathrm{~cm}+\frac{1}{2} \mathrm{~d}=$ $70 \mathrm{~cm}+\frac{1}{2} \times 60 \mathrm{~cm}=100 \mathrm{~cm}=1, \mathrm{~m}$, the

3. Area Comparison Ratio 1 Area Comperison Ratio $=$ Ratio

4. Broad Arm Length (A3)

With an arm length of $40 \mathrm{~cm}+\frac{1}{2} \mathrm{~d}=40$

\section{c. Axis Strength Calculation}

\section{Shaft Diameter}

Which :

Calculation of shaft with 150 watt of

$$
\begin{aligned}
& \mathrm{P}=150 \text { watts }=0,2 \mathrm{~kW} \\
& \mathrm{n}=45 \mathrm{rpm} \\
& \mathrm{f}_{\mathrm{c}}=2,0
\end{aligned}
$$

St $60=60 \mathrm{~kg} / \mathrm{mm}^{2}$

Calculation of shaft diameter :

$$
\begin{gathered}
\frac{p_{d}}{n} \\
\frac{U, 4}{40}
\end{gathered}
$$

$\mathrm{T}=9,74 \times 10^{5}$

$\mathrm{T}=9,74 \times 10^{5}$

$\mathrm{T}=9740 \mathrm{~kg} / \mathrm{mm}$ $d=\frac{2 A}{6 \pi d L}$

$d=\frac{2 \times 11,4}{6 \times 3.14 \times 2}$

$d=0.6$

So the dimensions of the type of turbine used is the type of savonius with dimensions $\mathrm{D} \times \mathrm{L}$ is $0,6 \times 1,2$ meters.

area obtained is as follows :

$L=P \times L=1 \times 2=2 \mathrm{~m}^{2}$

Comperison Ratio $=\frac{A_{1}}{A_{2}}=\frac{1_{1} / \mathbf{s}}{2}$

Area Comperison Ratio $=0,87$

$+\frac{1}{2} 50 \mathrm{~cm}=65 \mathrm{~cm}=0,65 \mathrm{~m}$, the area obtained is as follows :

$L=P \times l=0.65 \times 2=1,3 \mathrm{~m}^{2}$

power, turbine shaft rotation of 45 rpm, with a correction factor 2,0.

Assumption of material taken from $\mathrm{St}$ 60 steel bar.

$$
\begin{aligned}
& \mathrm{Pd}=\mathrm{f}_{\mathrm{c}} \mathrm{P} \\
& \mathrm{Pd}=2,0(0,2) \\
& \mathrm{Pd}=0,4
\end{aligned}
$$

Material St $60=60 \mathrm{~kg} / \mathrm{mm}^{2} ; S_{\mathrm{f} 1}=6,0$;

$\mathrm{S}_{\mathrm{f} 2}=2,0$

$\mathrm{Cb}=2,0 ; \mathrm{Kt}=1,5$ 


$$
\begin{aligned}
& \tau_{u}=\frac{a_{b}}{s_{f 1} \times s_{f 2}} \\
& \tau_{a}=\frac{00}{0,0 x z_{1} 0} \\
& \tau_{a}=5 \mathrm{~kg} / \mathrm{mm}^{2}
\end{aligned}
$$

\section{Calculation of Axle Bearings}

Which :

$$
\begin{aligned}
& \mathrm{d}_{\mathrm{s}}=26,21 \mathrm{~mm} \\
& m_{\text {rotortures }}=24 \mathrm{~kg}
\end{aligned}
$$

Material of Iron shaft St $60 \sigma_{b}=60$

$\mathrm{kg} / \mathrm{mm}^{2} ; \mathrm{S}_{\mathrm{f} 1}=6,0 ; \mathrm{S}_{\mathrm{f} 2}=2,0$

$$
\begin{array}{ll}
0,04<2,0 & \tau_{u}=\frac{0_{b}}{s_{f 1} x s_{f 2}} \\
V=\pi d \frac{n}{60 \times 100 v} & \tau_{u}=\frac{00}{0,0 x 2, \mathrm{u}} \\
\tau_{a}=5 K g_{m \text { mun }}
\end{array}
$$$$
\mathrm{n}=45 \mathrm{rpm}
$$

$$
\begin{aligned}
& 1=20 \mathrm{~mm} \\
& \mathrm{~d}=26,21 \mathrm{~mm}
\end{aligned}
$$

Material of Iron bronze $\mathrm{Pa}=0,7-2,0$

$$
\mathrm{kg} / \mathrm{mm}^{2}
$$

$$
\begin{aligned}
& \frac{1}{a} \leq \sqrt{\frac{1}{5.1}}+\frac{\sigma a}{b a} \\
& \frac{1}{a} \leq \sqrt{\frac{1}{5.1}}+\frac{b}{1,8}
\end{aligned}
$$

$$
\begin{aligned}
d_{s} & =\left(\frac{3,1}{\tau_{a}} K_{t} C_{b} T\right)^{1 / 3} \\
& d_{s}=\left(\frac{3,1}{4,4} \times 1,5 \times 2,0 \times 9740\right)^{1 / 3}
\end{aligned}
$$

So the shaft c $26.21 \mathrm{~mm} \quad 1$ is $26,21 \mathrm{~mm}$ so it's acceptable.

$3,14 \times 26,21 \frac{40}{\text { ธง } 200 \mathrm{v}}=0,05 \mathrm{~m} / \mathrm{s}(\mathrm{Pv})_{\mathrm{a}}=$ $0,45 \times 0,05=0,02 \mathrm{~kg} \mathrm{~m} / \mathrm{mm}^{2} \mathrm{~s}$ $P_{v}=0,2 \mathrm{~kg} \mathrm{~m} / \mathrm{mm}^{2} \mathrm{~s}$ (transmission shaft) The price $(\mathrm{Pv})_{\mathrm{a}}$ of the maximum transmission shaft allowed is $0,02 \mathrm{~kg}$ $\mathrm{m} / \mathrm{mm}^{2}$ s $0,02<0,2$ so it's acceptable.

\section{Analysis results}

The following area the results of turbine rotation data collection based on blade angle variations applied

Table 2 The data table results out the turbine rotation in turbine blade variations

\begin{tabular}{cccc}
\hline \multirow{2}{*}{ Trial } & \multicolumn{3}{c}{ Blade Angle Variation } \\
\cline { 2 - 4 } & Angle of $\mathbf{9 0}$ & Angle of $\mathbf{8 0}$ & Angle of $\mathbf{7 0}$ \\
\hline 1 & 68 & 56 & 45 \\
2 & 66 & 54 & 42 \\
3 & 69 & 51 & 39 \\
4 & 68 & 57 & 44 \\
5 & 67 & 60 & 45 \\
6 & 66 & 54 & 48 \\
7 & 66 & 55 & 43 \\
8 & 69 & 56 & 44 \\
9 & 66 & 54 & 43 \\
10 & 67 & 56 & 45 \\
11 & 65 & 57 & 46 \\
\hline
\end{tabular}




\section{Tibuana}

Journal of applied Industrial Engineering-University of PGRI Adi Buana

$p$-ISSN 2622-2027

$e$-ISSN 2622-2035

\begin{tabular}{cccc}
\hline 12 & 68 & 54 & 43 \\
13 & 67 & 58 & 46 \\
14 & 67 & 56 & 45 \\
15 & 66 & 59 & 39 \\
16 & 69 & 54 & 45 \\
17 & 68 & 56 & 44 \\
18 & 67 & 56 & 42 \\
19 & 68 & 54 & 43 \\
20 & 69 & 55 & 45 \\
Average & 67.3 & 55.6 & 43.8 \\
Standard Deviation & 1.22 & 2.04 & 2.19 \\
\hline
\end{tabular}

\section{Turbine Rotation Comparison Data}

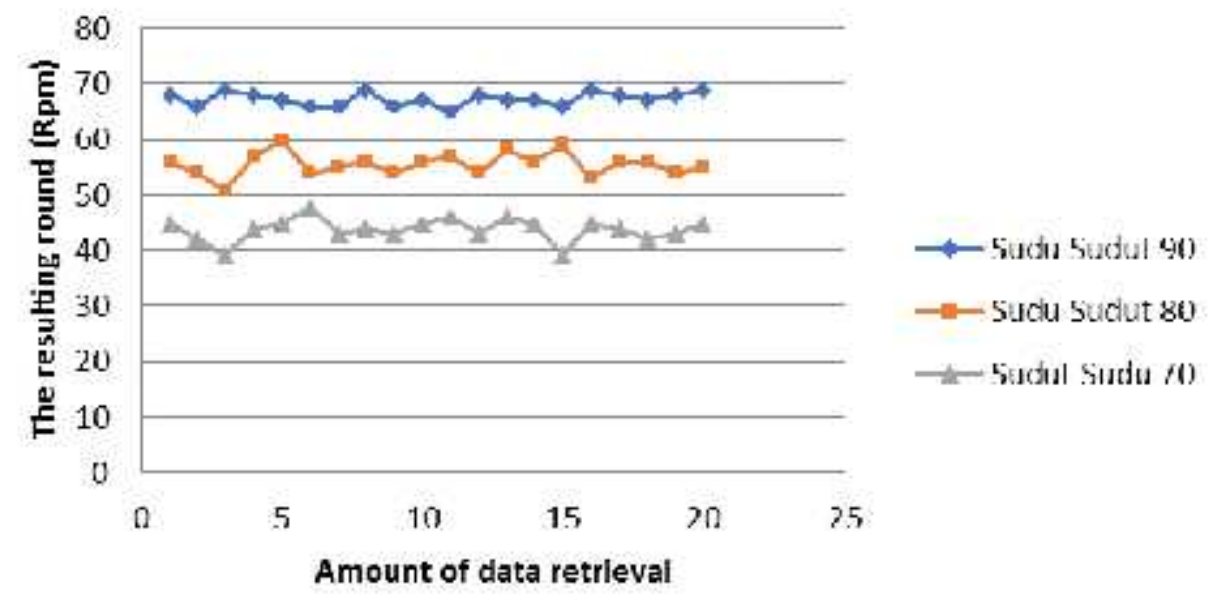

Picture 2. Turbines Rotation Comparison

The following is the result of turbine output voltage data based on the blade angle variations applied.

Table 3 The data table results from the output of turbine voltage in variations of the turbine blade

\begin{tabular}{cccc}
\hline \multirow{2}{*}{ Trial } & \multicolumn{3}{c}{ Blade Angle Variation } \\
\cline { 2 - 4 } & Angle of $\mathbf{9 0}$ & Angle of $\mathbf{8 0}$ & Angle of 70 \\
\hline 1 & 24 & 13 & 8.5 \\
2 & 20 & 12 & 6.7 \\
3 & 25 & 11.5 & 6.2 \\
4 & 24 & 14 & 8 \\
5 & 22 & 17 & 8.5 \\
6 & 20 & 12 & 10 \\
7 & 20 & 12.5 & 7.4 \\
8 & 25 & 13 & 8 \\
\hline
\end{tabular}

64 | TiBuana, Vol.2, No.2, 2019 


\section{Tibuana}

Journal of applied Industrial Engineering-University of PGRI Adi Buana

p-ISSN 2622-2027

$e$-ISSN 2622-2035

\begin{tabular}{cccc}
\hline 9 & 20 & 12 & 7.4 \\
10 & 22 & 13 & 8.5 \\
11 & 18 & 14 & 9 \\
12 & 24 & 12 & 7.4 \\
13 & 22 & 22 & 9 \\
14 & 22 & 13 & 8.5 \\
15 & 20 & 16 & 6.2 \\
16 & 26 & 12 & 8.5 \\
17 & 24 & 13 & 8 \\
18 & 22 & 13 & 6.7 \\
19 & 24 & 12 & 7.4 \\
20 & 25 & 12.5 & 8.5 \\
Average & 22.45 & 13.475 & 7.92 \\
Standard deviation & 2.24 & 2.43 & 0.99 \\
\hline
\end{tabular}

\section{Turbine Output Voltage Comparison Data}

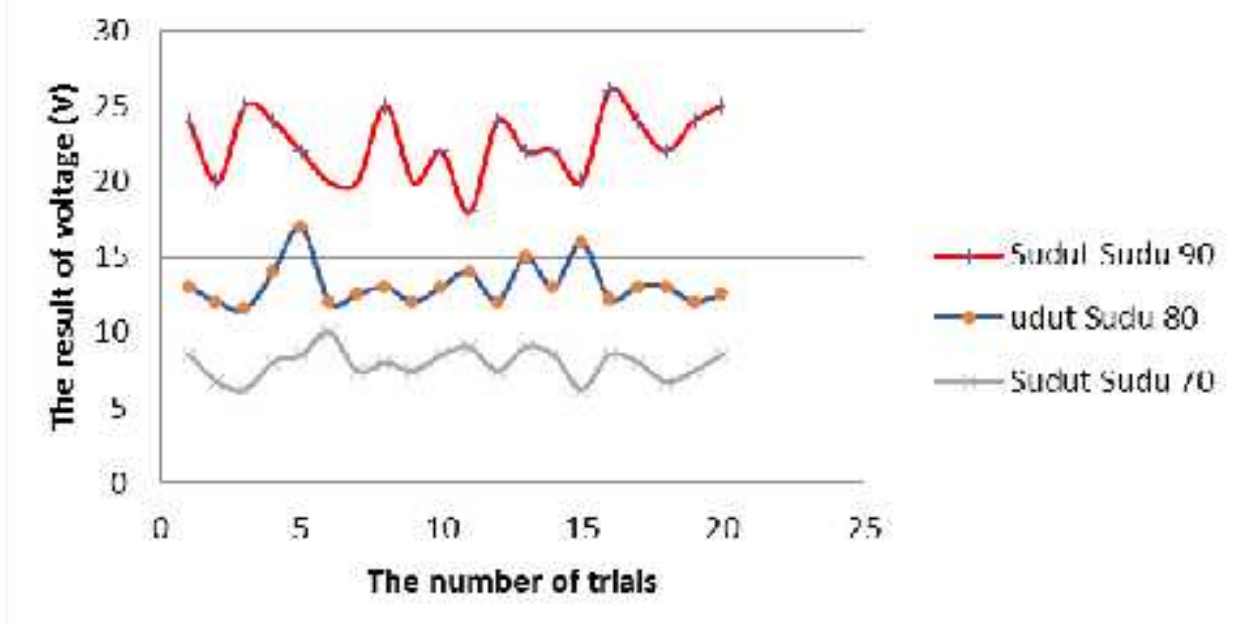

Picture 3. Turbines Output Voltage

The following is the result of turbine output voltage data based on the blade angle variations applied.

Table 4 The data table results from the output of turbine voltage in variations of turbine blade

\begin{tabular}{cccc}
\hline \multirow{2}{*}{ Trial } & \multicolumn{3}{c}{ Blade Angle Variation } \\
\cline { 2 - 4 } & Angle of 90 & Angle of 80 & Angle of 70 \\
\hline 1 & 2.7 & 1.7 & 0.89 \\
2 & 2.4 & 1.45 & 0.77 \\
3 & 2.8 & 1.3 & 0.67 \\
4 & 2.7 & 1.75 & 0.85 \\
\hline
\end{tabular}

TiBuana, Vol.2, No.2, $2019 \mid 65$ 


\begin{tabular}{cccc}
\hline 5 & 2.5 & 2 & 0.89 \\
6 & 2.4 & 1.45 & 1.1 \\
7 & 2.4 & 1.5 & 0.81 \\
8 & 2.8 & 1.7 & 0.85 \\
9 & 2.4 & 1.45 & 0.81 \\
10 & 2.5 & 1.7 & 0.89 \\
11 & 2.3 & 1.75 & 0.93 \\
12 & 2.7 & 1.45 & 0.81 \\
13 & 2.5 & 1.8 & 0.93 \\
14 & 2.5 & 1.7 & 0.89 \\
15 & 2.4 & 1.9 & 0.67 \\
16 & 2.8 & 1.45 & 0.89 \\
17 & 2.7 & 1.4 & 0.85 \\
18 & 2.5 & 1.7 & 0.77 \\
19 & 2.7 & 1.45 & 0.81 \\
20 & 2.8 & 1.5 & 0.89 \\
Average & 2.575 & 1.605 & 0.8485 \\
Standard deviation & 0.17 & 0.19 & 0.09 \\
\hline
\end{tabular}

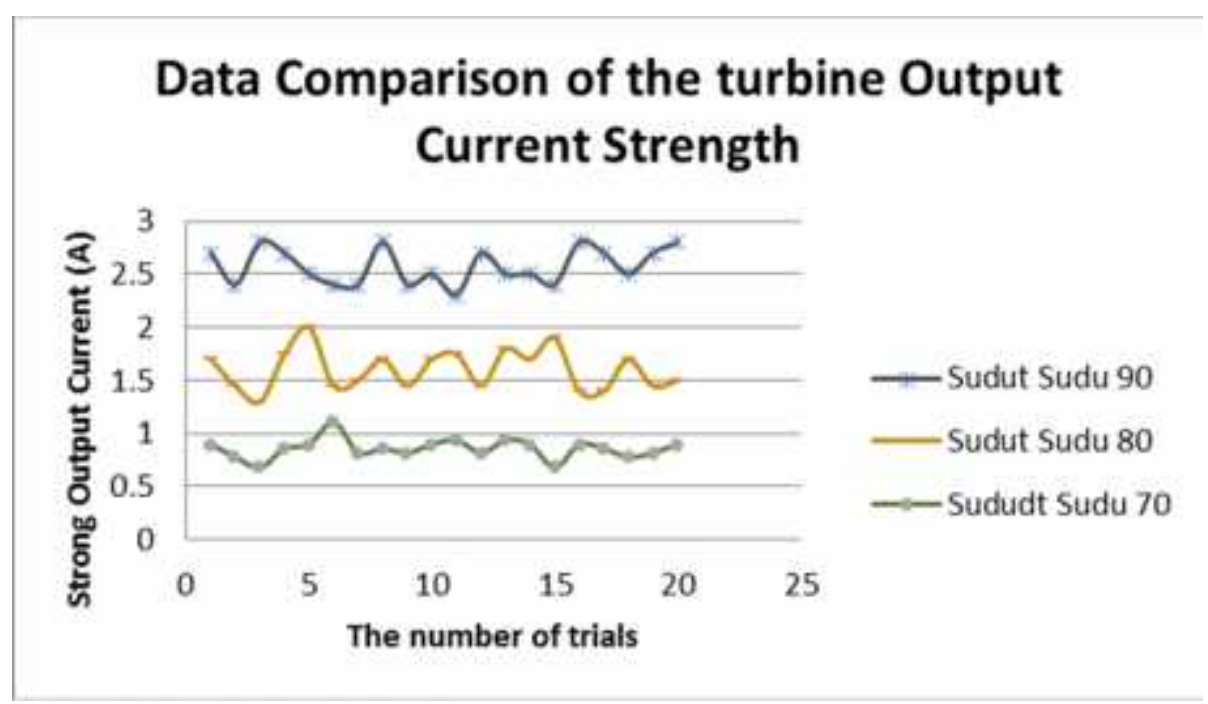

Picture 4. Data Comparison ot Turbine

Based on the results of data retrieval, it can be seen that in the turbine blade angle of $90^{\circ}$, there is a rotation, the output voltage and current strength are greater when compared to the application of other turbine blade angles,

\section{Conclusion}

The dimensions of the type of turbine used are the type of savonius type wind turbine with dimensions $\mathrm{D} \times \mathrm{L}$ is $0.6 \times 1.2$ meters. Arm with an average rotation of $67.7 \mathrm{Rpm}$. the rotation produces the output voltage and the average current is 22.45 Volt and 2.57 Ampere.

length $70 \mathrm{~cm}+\mathrm{d}=70 \mathrm{~cm}+\mathrm{x} 60 \mathrm{~cm}=100 \mathrm{~cm}=$ $1, \mathrm{~m}$, then the area obtained is. The shaft diameter used is $26.21 \mathrm{~mm}$. The price $(\mathrm{Pv})$ of the maximum transmission shaft allowed 0.02 


\section{Tibuana}

Journal of applied Industrial Engineering-University of PGRI Adi Buana

p-ISSN 2622-2027

$e$-ISSN 2622-2035

$\mathrm{kg} \mathrm{m} / \mathrm{mm} 2 \mathrm{~s} .0 .02<0.2$ becomes acceptable. Based on the results of data retrieval, it can be seen that in the turbine blade angle of $90^{\circ}$, there is a rotation, the output voltage and current strength are greater when compared to

\section{Reference}

Atmadi, Sulistyo, Ahmad Jamaludin, 2008, "Peneliti Pusat Teknologi Dirgantara Terapan", LAPAN.

Erich Hau, Wind Turbines Fundamentals, Technologies, Application, Economics, $2^{\text {nd }}$ Edition, terjemahan Horst von Renouard, Springer, Germany, 2005.

Khurmi RS Gupta, JK., 2005, Text Book of Machine Design Eurasia, Publising House, ltd Ram Nagar, New Delhi

the application of other turbine blade angles, with an average rotation of $67.7 \mathrm{Rpm}$. the rotation produces the output voltage and the average current is 22.45 Volt and 2.57 Ampere.

Sularso, kiyokatsu suga. 1978. Dasar perencanaan dan pemilihan elemen mesin. Jakarta. PT Pradnya Paramita.

Setioko, Bambang. 2013, 'Transformasi Ruang Perkotaan di Permukiman Nelayan (Studi Kasus: Tambakmulyo, Semarang)', Tata Loka, vol. 15, no. 3, hal. 192-207. 